\title{
GWAM-An Institutional Model to Address Watershed Impacts from Urbanization: Field Validation
}

\author{
Thambirajah Saravanapavan', Eiji Yamaji ${ }^{2}$ \\ ${ }^{1}$ Center for Water Resources, Tetra Tech, Inc., Fairfax, VA, USA \\ ${ }^{2}$ Department of International Studies, Graduate School of Frontier Sciences, The University of Tokyo, Tokyo, Japan \\ Email: tham.saravanapavan@tetratech.com,yamaji@edu.k.u-tokyo.ac.jp
}

How to cite this paper: Saravanapavan, $T$. and Yamaji, E. (2018) GWAM-An Institutional Model to Address Watershed Impacts from Urbanization: Field Validation. Journal of Water Resource and Protection, 10, 906-918.

https://doi.org/10.4236/jwarp.2018.109053

Received: March 27, 2018

Accepted: September 15, 2018

Published: September 18, 2018

Copyright (c) 2018 by authors and Scientific Research Publishing Inc. This work is licensed under the Creative Commons Attribution International License (CC BY 4.0).

http://creativecommons.org/licenses/by/4.0/

\begin{abstract}
With the realization of the limitations to top-down and bottom-up watershed management approaches in addressing issues associated with urbanization, a conceptual framework for a hybrid approach that tries to effectively integrate the advantages of the two approaches while overcoming their respective limitations, grass root watershed management model (GWAM), was proposed and presented. This paper presents the details of implementation and validation of GWAM at Shawsheen River watershed in Massachusetts, USA. An investigation on the major components of GWAM, a common platform to conduct the management, a partnership of two major stakeholder groups from government and non-governmental organizations, and a facilitation mechanisms were carried out in detail to gain the needed understanding on structure, process and function of a successful GWAM. Also the decision making process in addressing three major urban watershed issues; flooding, habitat and aquatic life impairment, and bacterial impairment, were examined through a set of cyclic steps. Based on the lessons learned, GWAM was enhanced as a general hybrid model. The most important challenge in sustaining GWAM was to keep differently motivated stakeholders together. As revealed in the Shawsheen watershed, science should play a key role in keeping differently motivated stakeholders together by providing needed facts, understandings, data, and knowledge. When scientifically sound solutions are vetted through a process of public involvement that supports appropriate regulatory actions, the most effective environmental decisions can be made.
\end{abstract}

\section{Keywords}

Watershed Management, Urbanization, Interdisciplinary, Institutional 
Model, Top-Down, Bottom-Up

\section{Introduction}

Urban areas all over the world are growing at unprecedented rates, creating extensive urban landscapes. Natural lands, such as forest, wetlands, shrubs and bushes, have been converted to buildings, roads, parking lots, and urban turf lands. The urbanization process exerts negative multidisciplinary impacts on the integrity of natural watershed conditions. These impacts are best analyzed and addressed with local inputs, as many of these are site specific and require consistent local monitoring along with appropriate policies and regulations from conventional governance in an interdisciplinary platform. It requires a collaborated, committed, and continued (3C) approach of all sections of stakeholders in the watershed through an interdisciplinary forum within an effective watershed management context.

With the realization of the limitations to top-down and bottom-up watershed management approaches in addressing issues associated with urbanization, a conceptual framework for a hybrid approach that tries to effectively integrate the advantages of the two approaches while overcoming their respective limitations, grass root watershed management model (GWAM), was presented in acompanion paper in this issue [1]. The hybrid approach consists of three crucial components: a common platform, a partnership among major groups of stakeholders, and a facilitation mechanism to conduct the watershed management at local level or grass-root level (Figure 1). With effective integration of the governmental agencies and institutes at the top with the local residents and non-governmental organizations at the bottom, the hypothesis is that the hybrid approach can serve as a self-sustaining model in achieving effective management of urbanization

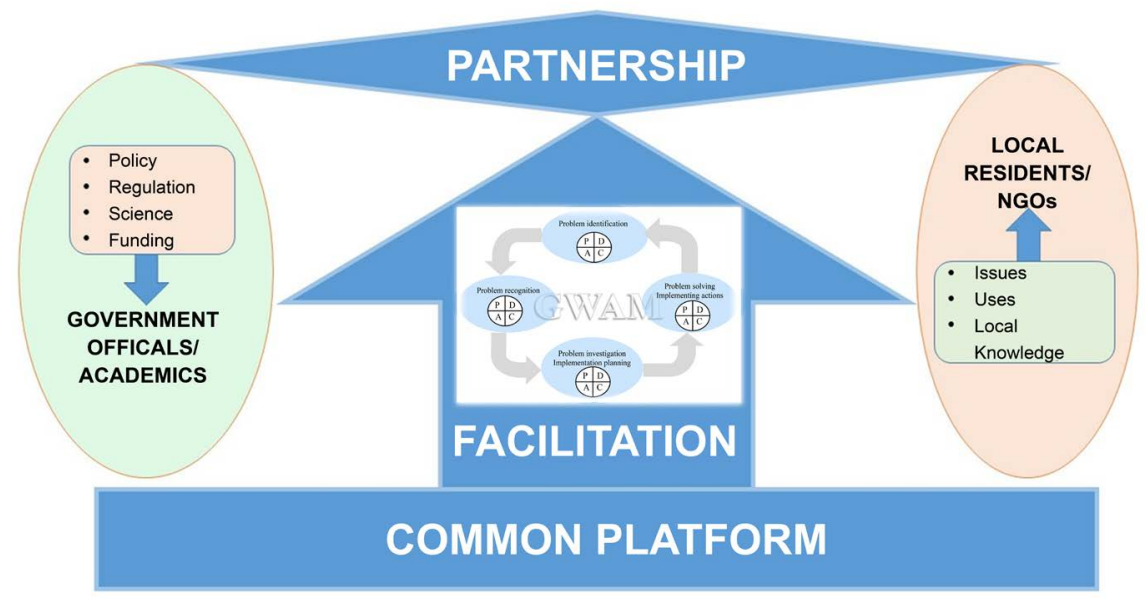

Figure 1. Conceptual self-sustaining GWAM model with common platform to convene, partnership among major stakeholder groups and effective facilitation of decision making towards sustainable watershed management [1]. 
impacts. Despite the positive recognition, there is little or no real-world application on how the hybrid approach could potentially help addressing urbanization.

The GWAM model was implemented and verified at the Shawsheen River Watershed in Massachusetts, USA (Figure 2). The watershed has experienced intensive urban developments, causing deteriorations in physical and water quality conditions. Components of the GWAM model were implemented in the watershed to help with the management process, especially to help address the multidisciplinary problems that are common to urbanization processes. This paper presents the details of model implementation and also it presents the enhanced GWAM with lessons learnt from the field application.

\section{Implementation of GWAM at Shawsheen}

\subsection{Urbanization Impacts}

The Shawsheen River Watershed drains an area of about $200 \mathrm{~km}^{2}$ to the northwest of the Boston metropolitan area in eastern Massachusetts, USA. Notably, the installation of the Hanscom Air Force Base (HAFB) in 1942 was one of the most striking changes to the nature of this watershed. Significant amount of pervious land (natural land) was converted to impervious land (modified land) as a result of the construction of runways, office buildings, parking lots, roads,

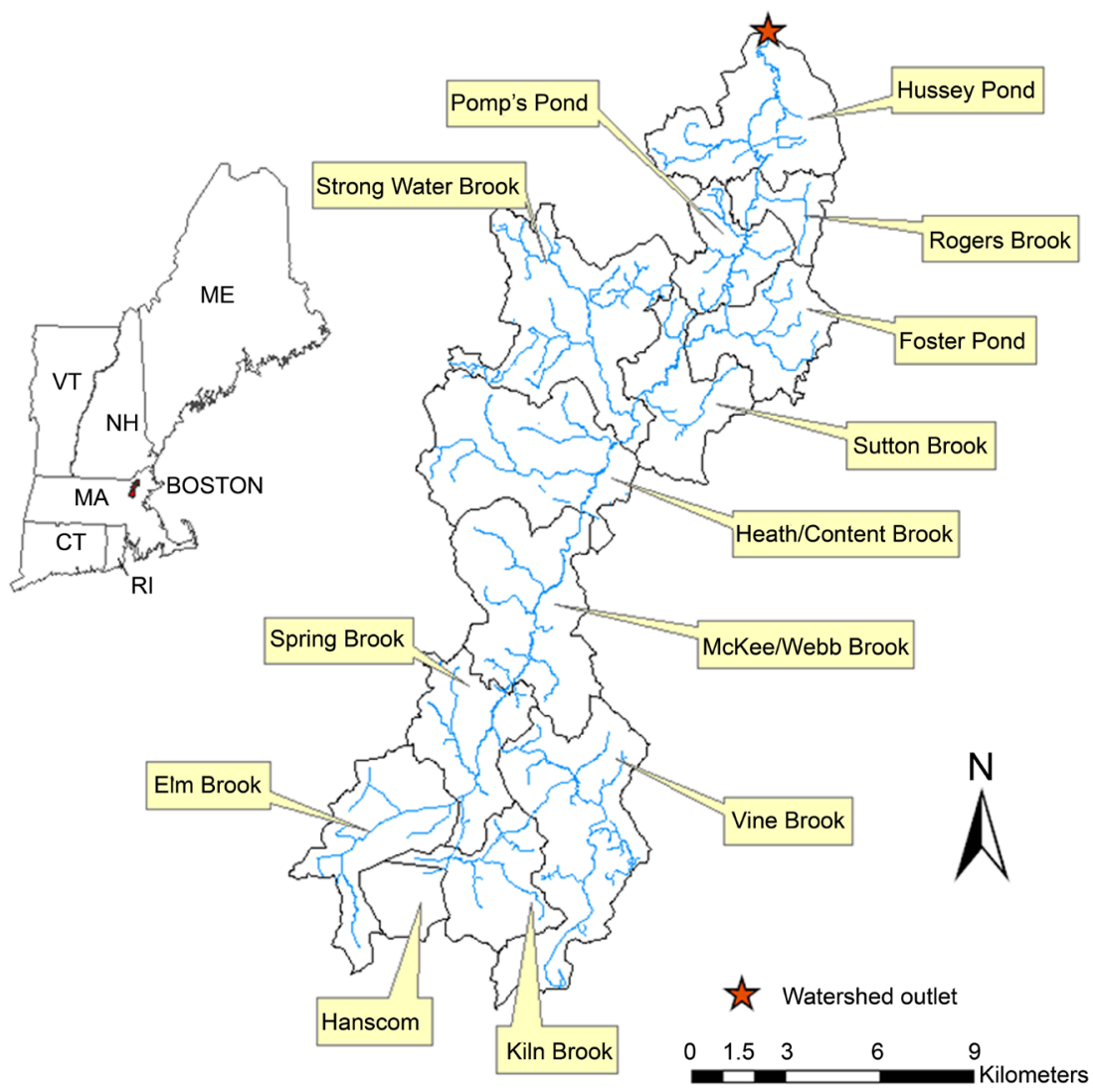

Figure 2. The location of the Shawsheen River Watershed in the Northeastern United States, near Boston Metropolitant area, and its thirteen sub-watersheds. 
residences, etc. The natural channels and streams were replaced by concrete culverts and deepened and widened channels to accommodate the stormwater runoff from increased impervious surface. According to [2], about $66 \%$ of the land in the Shawsheen River Watershed was covered by forested land (wooded trees), wetland, natural crop and pasture in 1930s. But it was reduced to about $34 \%$ by the year of 1999. This alone explains the conversion of land uses in the watershed. Also, the Shawsheen River was placed on the state of Massachusetts' list of impaired water bodies for pathogens, sediment and siltation, metals, turbidity, nutrients, organic enrichment and low dissolved oxygen, and other habitat alteration [3].

The urbanization process has caused substantial degradations in the hydrological [2], ecological [4], and biological [5] conditions in the Shawsheen River Watershed. One of the common stressors, fully or partially contributing, to these impacts is excess stormwater [4]. Corresponding with the comprehensive impacts, solutions to mitigating the adverse impacts also require comprehensive measures that cross the several noted disciplines.

\subsection{GWAM Setup}

A GWAM framework [1] was implemented specifically to address urbanization impacts in the Shawsheen River Watershed. Key components to the GWAM framework include a permanent platform for all interested parties to commit and communicate, a stable partnership of key players to collaborate, and a continuous and dynamic facilitation mechanism that continue to address issues and to adopt to changes.

\subsubsection{The Platform: Massachusetts Watershed Initiative}

Massachusetts Watershed Initiative (MWI) is one of the successful initiatives in USA [6] as a community based environmental planning and management institutional program. It is a shift from traditional top-down, federal and state driven environmental management to grassroots, locally focused management. MWI coordinated municipal, state, and federal governments, businesses, local residents, watershed associations and other non-profit organizations to improve the effectiveness of their individual efforts to prevent and repair environmental pollution at local level. Accordingly, the state of Massachusetts divided its watersheds into twenty-seven watershed units (27 GWAM Units). Each unit has a watershed team that includes representatives from local, state, and federal groups, led by a full-time state appointed team leader. The Shawsheen Watershed Team (SWT) is one of twenty-seven teams formed in 1996 [7] under the MWI. This GWAM unit directed environmental protection efforts of the Shawsheen River watershed. The governing system of the SWT, over a five-year period, between 1998 and 2003, is analyzed and presented below.

\subsubsection{The Partnership: Shawsheen Watershed Team (SWT)}

SWT was composed of members and representatives from public sector, private 
sector, and non-governmental organizations and private citizens. SWT included two major groups of the stakeholders as presented in Figure 3. The first group was composed of private residents, non-governmental organizations, Shawsheen River Watershed Association (SRWA) and Merrimack River Watershed Council (MRWC) and private business and industries, Raytheon, Limno Tech, and Environmental Scientific Services. Flooding, drought and/or water quality related issues in the watershed motivated this group, because their life were directly or indirectly impacted by the watershed issues. The second group was composed of municipal, state, and federal government employees, who were responsible to implement government policies or programs and enforce the regulations of respective governments. This group was mainly motivated through job functions. Although the individual motivation for involvement varies among the members, the collective goal was protecting and restoring the Shawsheen watershed.

\subsubsection{The Facilitation Mechanism: Quarterly Meetings}

The major forum in facilitating the watershed management by SWT was the quarterly meeting. The watershed team leader had prepared agendas and facilitated the meetings. Quarterly meetings had generally lasted about 2 hours and the first 30 - 45 minutes were allocated for the team members to report their activities. One quarterly meeting was generally allocated for the development of an annual plan. The rest were to review the progress of ongoing priority projects and to address the issues brought up by the team members. Occasionally, SWT invited experts to give presentations on the topics of team's interest. During the five year period analyzed for this research, SWT conducted 18 quarterly meetings. On average 20 people attended these meetings and among the attendees 13 and 7

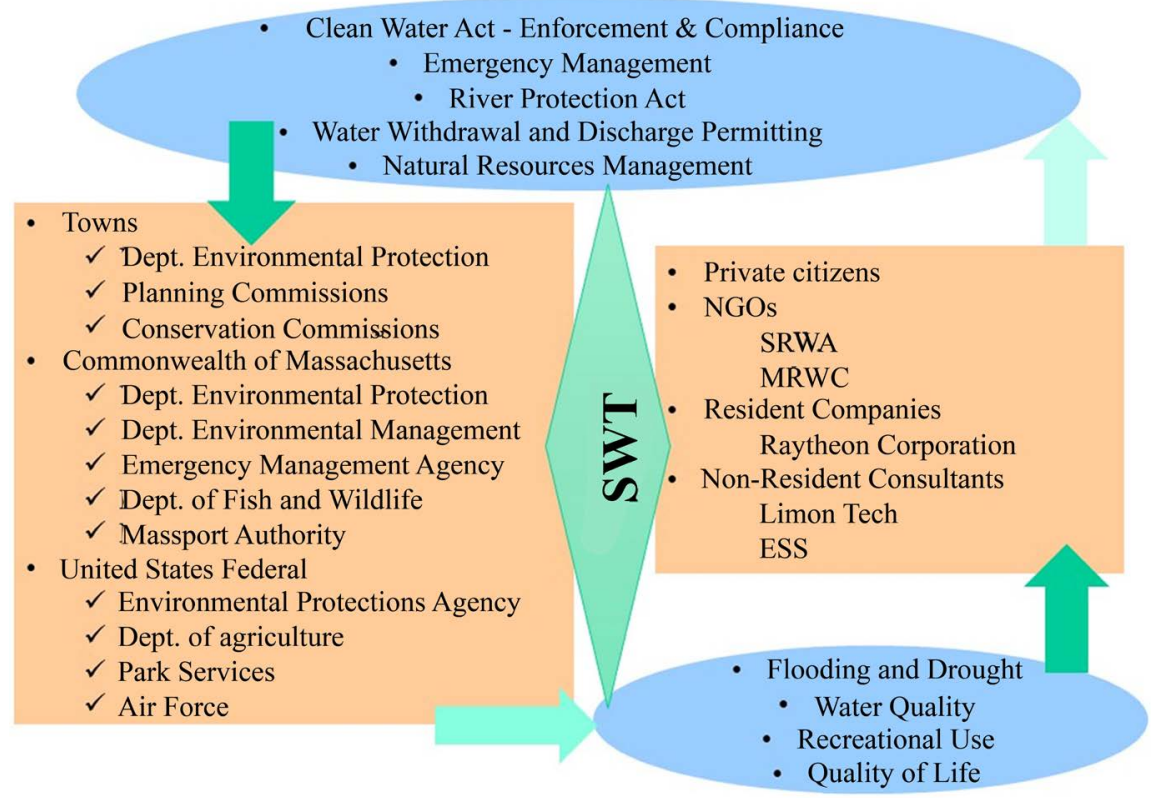

Figure 3. Composition of SWT-state and federal agencies, municipal partners, business, industries, regional authorities, NGOs, and private citizens. 
people from government and non-government sectors respectively. It was observed that 7 people from state government and 4 people from non-governmental organizations had consistently attended and formed the core of the watershed team. If the issues required special attention, sub-committees or steering committees were formed. For example, steering committees were formed in 1997 and 2002 to develop five-year plans. In between 1998 and 2003, SWT developed two five-year plans. In both cases, steering committees were responsible for developing these plans.

\subsection{Addressing Issues through GWAM}

With major GWAM components in the Shawsheen watershed being identified, the GWAM processes that were employed for resolving land use change and urbanization related issues in the watershed is further explored in this section. As previously mentioned, the land use change in the Shawsheen watershed has caused deteriorations in hydrological, ecological and biological aspects. Therefore, the applications of the characteristics of GWAM model in addressing these three issues are discussed accordingly in the following subsections.

\subsubsection{Addressing Flooding Issue}

Urbanization and associated impacts resulted in frequent floods in Shawsheen River Watershed. In addition, a significant drought was observed during the summer of 1999, during which a few segments of the Shawsheen River primarily used for recreational activities almost dried out in this summer [7]. Other than the physical observations and experiences, SWT had no scientific evidences and support to bring the involvement of local decision makers and government agencies together to address the issue. SWT launched several efforts including a study to understand the impact of urbanization on hydrological balances in the watershed and to educate local officials and decision makers in order to integrate these understanding in practice [7]. SWT addressed the hydrological issues through $3 \mathrm{C}$ approach in a cyclic set of steps, problem identification, problem recognition, implementation planning and policy adoption, and problem solving and implementing actions, as presented in [1].

A detailed hydrological balance investigation [2] revealed substantial reduction in watershed base flow and increase in surface runoff, especially in highly developed subwatersheds. It shifted the focus of flood mitigation efforts from conventional hydraulic solutions to watershed-based solution to address low flow and flood flow issues simultaneously. The study introduced a simple tool [8] to understand the impacts of base flow and assisted SWT in planning best management practices (BMP) to address such impacts. The tool also stimulated local legislators and municipalities and other decision makers to adopt watershed based flood mitigation policies. SWT conducted an educational campaign to spread the understanding throughout the watershed. A workshop was conducted to educate municipal officials on watershed based flood solutions and to introduce innovative BMPs and practices that would increase infiltration 
while reducing the magnitude of peak flow and the volume of surface runoff. SWT also conducted further investigations [9] at the worst impacted subwatershed in the Shawsheen headwaters of Hanscom, where the base flow was reduced by fifty percent due to urbanization [2]. These investigations made HAFB, an active member and contributor of SWT, to develop a long-term stormwater management plan [10] to minimize the runoff generation and to maximize the groundwater recharge by following the planning principles adopted by SWT. The Massachusetts Port (Massport) Authority, another SWT member, also begun to implement BMPs in Hanscom airport to minimize the adverse impacts of stormwater flow.

\subsubsection{Addressing Aquatic Life and Habitat Issue}

To effectively address the aquatic life and habitat issue and restore the impaired headwaters, SWT deemed that a watershed-wide approach was necessary bring the stakeholders together to make appropriate decisions related to this impairment. SWT addressed this issue through 3C approach in a cyclic set of steps, problem identification, problem recognition, implementation planning and policy adoption, and problem solving and implementing actions, as presented in [1].

In the United States, the state governments must notify the federal government through 303 (d) list of impaired waters that fails to meet state's water quality standard under the Clean Water Act (CWA). Data collection in the Shawsheen headwaters documented habitat and aquatic life impairments and that resulted in placing a three-kilometer headwater river segment in the impairment list of Massachusetts 303 (d) list. Subsequent comprehensive data collection [11] by SWT confirmed the existence of these impairments. The data analysis concluded that multiple stressors were involved in the impairment. However, there was not enough information to understand the relative contribution of each stressor and to link the sources and causes of the problem. The overall focus of SWT was to develop a restoration plan. The team recognized that developing a Total Maximum Daily Load (TMDL) was an appropriate avenue to address this issue. TMDL is a management or cleanup plan that sets a pollutant cap or ceiling. The cap is a formula that represents the maximum amount of a pollutant that a water body can receive and still meet the water quality standards. TMDL development in this case was a challenge as no conventional pollutants, such as sediment, bacteria, nutrient, or metals, which have the history in TMDL development, are directly associated with the impairment. Based on these challenges, a new approach [4] was introduced to use hydrology as an umbrella to address all stressors associated with main source, storm water, for aquatic life impairments in urban environment. As a result, a TMDL [12] was developed. SWT adopted the targets identified and set the goals of storm water management for the headwater subwatershed. The HAFB, which owns the two-third of the drainage area in the headwater subwatershed, decided to install best management practices. 


\subsubsection{Addressing Bacteria Issue}

Bacteria impairment and related issues have been felt and addressed by the state and local agencies [13], [14] before the formation of SWT. Therefore, when SWT was formed, one of the initial goals of SWT was to reduce bacteria loading in the Shawsheen River and its tributaries to meet the Massachusetts Water Quality Standards and remove the listed sections of the Shawsheen from the 303 (d) list for bacteria impairments.

To effectively address the bacteria impairment throughout the watershed, SWT deemed that a watershed wide approach was necessary to bring the stakeholders together to make appropriate decisions and actions related to this issue. SWT has launched several efforts, including data collection and analysis, TMDL development, planning restoration efforts, educating the local officials and decision makers, and integrating these understanding into practice [7] in a cyclic set of steps, problem identification, problem recognition, implementation planning and policy adoption, and problem solving and implementing actions, as presented in [1].

Based on the data collected in 1995, the state of Massachusetts placed the Shawsheen River in its 303 (d) list of impaired waters under CWA [3]. As a result, the state was required to develop a TMDL, implement, and restore the Shawsheen from bacteria contamination. The 1995 monitoring results also have generated team's interest in further investigation, including a continuous monitoring during 1996-1999 [11]. It is important to note that SWT raised funds separately without using the annually allocated team's fund from the state government under MWI for the monitoring project [7]. The data collected gave the team a much more comprehensive view of water quality throughout the watershed. The data were also used to develop a Bacteria TMDL for the Shawsheen River [15]. As previously mentioned, TMDL sets a pollutant cap or ceiling that a water body can receive while still meeting the water quality standards. The Shawsheen TMDL was set that the river and tributaries should approximately reduce the bacteria contamination by $90 \%$ [15] to meet the state's water quality standard. Although the team was motivated to eliminate the bacteria contamination, there was no clear direction or studies to guide the team in controlling bacteria sources in urban environment to meet the water quality standard. In order to assist the team, a scientific investigation [5] was conducted to understand the capability of bacteria control measures in meeting water quality standard. A few consistent dry weather contributions were also found to be potentially associated with sewer breaks/leaks. Catchbasins or stormwater inlets (to collect storm water from streets) with high sediment deposition were found to contribute high bacteria load to the river. Residential areas with signs of pet activities were also found to contribute high bacteria load to the river. Another source commonly found was urban wild life such as geese. On the other hand, the controlled sites, with a successful sewer leak/break detection and elimination program, pet waste management and education program, and proper pollution prevention such as 
frequent street sweeping and catch basin clean up, were found to contribute no bacteria loading during dry weather flows. In addition, the wet weather bacteria loads from the controlled sites were also substantially lower at one or two magnitudes lower in order. As a result of this study, SWT adopted sewer leak/break detection and elimination, proper catchbasin clean up and street sweeping, and pet waste management and education, all of which were adopted as the primary control actions to protect the Shawsheen River from bacteria contamination [7].

\subsection{Effectiveness of GWAM}

Prior to formation of SWT, no governmental or non-governmental organization existed to specifically address the protection of the Shawsheen watershed at the same forum. Federal, state, and local agencies independently performed some activities of watershed protections within their mandates and boundaries. A non-governmental organization, (Merrimack River Watershed Council (MRWC), was the only private organization existed to address the watershed protection within watershed boundaries. However, the focus of MRWC was the entire Merrimack Basin of $12,976 \mathrm{~km}^{2}$. The Shawsheen $\left(200 \mathrm{~km}^{2}\right)$ is one of the seventeen watersheds in the Merrimack River Basin. Therefore, no coordinated effort, commitments from organizations including governmental and non-governmental, and permanent establishments existed to conduct watershed management to protect and restore the Shawsheen River. It is important to note that SWT is the first platform formed to conduct the watershed management by integrating all stakeholders including governmental and non-governmental organizations in the Shawsheen River Watershed. It is also important to note that a new non-governmental organization, Shawsheen River Watershed Association (SRWA), was formed through the organization, function, and facilitation of SWT's watershed management processes. Although the government agencies or non-government agencies had meetings and forums to address their objectives independently, the quarterly meetings of SWT is the first forum to facilitate all stakeholders under a single umbrella. It helped to exchange ideas and knowledge otherwise would not have been available to the stakeholders. Another important characteristic that existed in SWT and would not be existed in the conventional approach was sharing the responsibility. Through comprehensive planning and coordinated actions, SWT demonstrated that the same resources and knowledge could be effectively used when put together and shared rather than isolated and used on an individual basis.

State government had allocated $\$ 100,000$ yearly for priority watershed projects identified by SWT. From 1998 through 2003, the team received $\$ 430,000$ in total project funding to address its priorities [7]. In addition, the team members brought in $\$ 425,000$ during the same period as matched support to the team's priorities through non-governmental and other resources. These estimations exclude the time and effort voluntarily provided by the team members. This includes watershed wide physical, chemical, and biological monitoring, habitat 
and biological assessments, pollution remediation planning and implementation, GIS data acquisition, TMDL development, water balance analysis, flood mitigation planning, riverbank erosion mitigation, river clean ups, and development of Shawsheen recreation map.

\section{Field Verified GWAM}

\subsection{Sustain GWAM}

To successfully implement watershed planning and management through GWAM, it is important to have the appropriate platform, partnership and facilitation in place [1]. In the meantime, it is equally important to sustain these key components for a long-term so that meaningful planning, actions and management can be applied to address the watershed issues. The most important challenge in sustaining GWAM was to keep differently motivated stakeholders together on a single goal of protecting the watershed. Differences in understanding, knowledge, job functions, education level, intended use of water resources, and resources availability make stakeholders tend to differ in opinion, priority, and decision making. As investigated and revealed in the Shawsheen watershed, science played a key role in keeping differently motivated stakeholders together by providing needed facts, understandings, data, and knowledge. This facilitated the stakeholders to come up with well informed and educated decisions that kept the process moving without substantial differences. With the integration of scientific data collection, modeling analysis, TMDL development, innovative tools, and gap analysis, the initial opinion, doubts, and understandings of diverse stakeholders were brought to common knowledge, opinion, and direction. Nominal funding availability, partial salary of the government appointed team leader and the fund for priority projects, also played a key role in keeping the stakeholders together in the Shawsheen example.

One of the central themes for the success of a GWAM unit is the appropriate integration of science into decision-making (Figure 4). When scientifically sound solutions are vetted through a process of public involvement that supports appropriate regulatory actions, the most effective environmental decisions can be made. In addition, when the science was successfully integrated into policy and decision-making, with satisfying regulations, it motivated all players. This is true regardless of whether they are concerned with enforcing regulation, complying with regulation, or caring for the watershed where they live. Nominal funding was an additional need to sustain GWAM unit. It is important to note that funding was raised not only through government agencies but also equally brought by the community and other local players. All of the mentioned scientific integration into GWAM can be made possible by injecting nominal funding to sustain it.

\subsection{Conclusions and Recommendation}

A hybrid GWAM is proposed for assisting decision-makers to improve watershed 


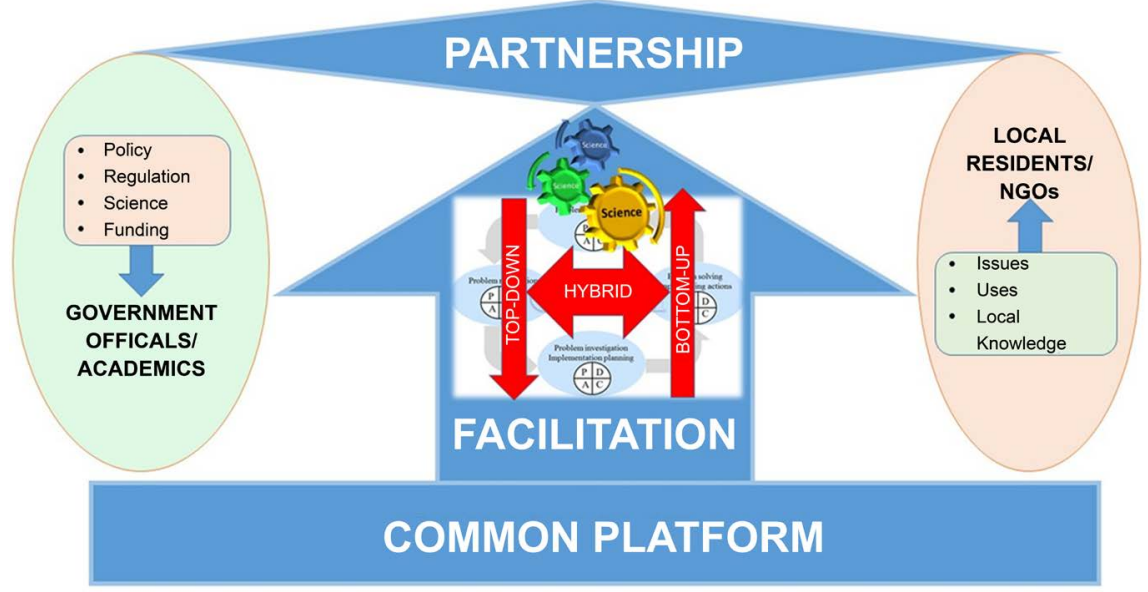

Figure 4. Enhanced GWAM model from the lessons learned. The successful watershed management witnessed when the strength of top-down and bottom-up approaches are linked in hybrid model with appropriately integrated science in interdisciplinary decision making.

management. The institutional model overcomes the common limitations posed in both the traditional top-down approach and the more recent bottom-up approach, and instead emphasizes on effective collaboration between government agencies and local stakeholders. The GWAM model consists of three major components: a permanent platform for all parties to interact and to communicate, a partnership that consists of at least two major stakeholders in the watershed, and a facilitation mechanism that sustains the model for long-term operations.

The GWAM conceptual model was implemented at the Shawsheen watershed in Massachusetts, USA for coping with the adverse hydrological, ecological, and biological effects resulting from the urbanization process. All three components of the GWAM model were implemented accordingly in the Shawsheen watershed to assist with the watershed management process. Through effective integration of science into the decision making process, the GWAM model was able to identify appropriate solutions to each of the three issues that were present in the watershed. While the GWAM has been successfully implemented at the Shawsheen watershed for comprehensive watershed management and has advanced in the body of knowledge in using hydrology as surrogate for watershed management, there are still aspects in the model that future research can help further enhance the model.

One immediate area that future research on GWAM could be expanded into is to test the model on more locations. While the Shawsheen watershed serves as a typical watershed that experiences hydrological, ecological, and biological issues resulting from urbanization and a watershed with good mix of household economic backgrounds, the watershed is from a developed country where the public awareness are high and political wills are strong. It would be very interesting to implement GWAM model in a developing world and compare the re- 
sults to the Shawsheen example. It is expected that the geographical, political, and cultural settings may have different weights and may potentially lead to adjustments to the current GWAM model setup.

\section{Acknowledgements}

Authors would like to express our gratitude for Dr. Guoshun Zhang, for his time in reviewing the research findings and providing valuable feedback. Also the authors would like to thank Mr. William Dunn, Massachusetts Department of Environmental Protection, for allowing us to access to archived materials on the Shawsheen River Watershed and spending time to answer all of our inquires on SWT. The constructive comments provided by the anonymous reviewers also helped improving the paper and are greatly appreciated.

\section{Conflicts of Interest}

The authors declare no conflicts of interest regarding the publication of this paper.

\section{References}

[1] Saravanapavan, T. and Yamaji, E. (2018) GWAM-An Institutional Model to Address Watershed Impacts from Urbanization: Conceptual Framework. Journal of Water Resources and Protection, 10, 896-905. https://doi.org/10.4236/jwarp.2018.109052

[2] MRWC (Merrimack River Watershed Council) (2000) Water Flow Analysis: Shawsheen River Basin. Final Report, MA Executive Office of Environmental Affairs, Boston.

[3] MADEP (Massachusetts Department of Environmental Protection) (1999) Final Massachusetts Section 303(d) List of Waters, 1998. Division of Watershed Management, Massachusetts Department of Environmental Protection, Worcester.

[4] Saravanapavan, T., Yamaji, E., Voorhees, M. and Zhang, G. (2014) Using Hydrology as a Surrogate in TMDL Development for Impairments Caused by Multiple Stressors. Advances in Water Resource and Protection, 2, 1-10.

[5] MRWC (Merrimack River Watershed Council) (2003) Shawsheen Bacteria TMDL Implementation Plan. Final Report. Project Number: 2001-01/MWI. Massachusetts Executive Office of Environmental Affairs, Boston.

[6] Michaels, S. (2001) Making Collaborative Watershed Management Work: The Confluence of State and Regional Initiatives. Environmental Management, 27, 27-35. https://doi.org/10.1007/s002670010131

[7] Massachusetts Executive Office of Environmental Affairs (2003) Shawsheen River 5-Year Watershed Action Plan 2003-2008. MA Executive Office of Environmental Affairs, Boston.

[8] Saravanapavan, T., Anbumozi, V. and Yamaji, E. (2004) Using Percent Imperviousness as a Planning Tool in Watershed Management: Case Study of the Shawsheen in USA, Transactions of Association of Rural Planning, 23, 73-78. https://doi.org/10.2750/arp.23.23-suppl_73

[9] MRWC (Merrimack River Watershed Council) (2001) HanscomStormwater System Computer Model-Model Development and Calibration. Final Report, MA Execu- 
tive Office of Environmental Affairs, Boston.

[10] Fuss and O’Neill (2011) Final Storm Water Management Plan for Hanscom Air Force Base, US Air Force, Concord.

[11] MRWC (Merrimack River Watershed Council) (1999) Shawsheen River Watershed 1996-1998 Volunteer Monitoring Report, MA Executive Office of Environmental Affairs, Boston.

[12] MADEP (Massachusetts Department of Environmental Protection) (2003) Draft Storm Water Pollutant Total Maximum Daily Load for Headwaters of the Shawsheen River, Division of Watershed Management, Massachusetts Department of Environmental Protection, TMDL Report MA83-08-2003-01, DWM Control Number CN: 168.00.627, Worcester.

[13] MADEP (Massachusetts Department of Environmental Protection) (1990) Shawsheen River 1989 Water Quality Survey Data and Water Quality Analysis, Division of Water Pollution Control, Massachusetts Department of Environmental Protection, Publication No. 16, Worcester.

[14] MADEP (Massachusetts Department of Environmental Protection) (1996) MADEP. 1996. 1995 Shawsheen Assessment Summary Report. Bureau of Resource Protection, Massachusetts Department of Environmental Protection. Worcester.

[15] MADEP (Massachusetts Department of Environmental Protection) (2002) Draft Bacteria TMDL for the Shawsheen River Basin. Bureau of Resource Protection, Department of Environmental Protection. Draft Report MA83-01-2002-24, Worcester. 